\title{
STAT3 is involved in phosphatidic acid-induced Bcl-2 expression in HeLa cells
}

\author{
Hye-Jin Choi ${ }^{1 *}$, Jung Han Lee ${ }^{2 *}$, \\ Shin-Young Park', Ju Hwan Cho' \\ and Joong-Soo Han ${ }^{1,3}$ \\ ${ }^{1}$ Department of Biochemistry and Molecular Biology \\ ${ }^{2}$ Obstetrics and Gynecology \\ College of Medicine \\ Hanyang University \\ Seoul 133-791, Korea \\ ${ }^{3}$ Corresponding author: Tel, 82-2-2220-0623; \\ Fax, 82-2-2294-6270; E-mail, jshan@ hanyang.ac.kr \\ *These authors contributed equally to this work. \\ DOI 10.3858/emm.2009.41.2.012
}

Accepted 29 October 2008

Abbreviations: AA, arachidonic acid; DPPA, 1,2-dipalmitoryl-snglycero-3-phosphate; LPA, lysophosphatidic acid; PA, phosphatidic acid; PAP, PA phospholyhydrolase; STAT3, signal transducer and activator of transcription 3

\begin{abstract}
Phosphatidic acid (PA), the product of a PLD-mediated reaction, is a lipid second messenger that participates in various intracellular signaling events and is known to regulate a growing list of signaling proteins. We found that Bcl-2 was upregulated by PA treatment in HeLa cells. However, how PA upregulates Bcl-2 expression has not yet been studied. In this study, we tried to discover the mechanisms of Bcl-2 up-regulation by PA treatment in HeLa cells. Treatment with PA resulted in significantly increased expression of Bcl-2 in HeLa cells. Moreover, PA-induced Bcl-2 expression was blocked by mepacrine, an inhibitor of PLA, but not by propranolol, an inhibitor of PA phospholyhydrolase (PAP). Treatment of 1,2-dipalmitoryl-sn-glycero-3phosphate (DPPA) also increased Bcl-2 expression. These results indicate that $\mathrm{Bcl}-2$ expression is mediated by lysophosphatidic acid (LPA), not by arachidonic acid (AA). Thereafter, we used MEK1/2 inhibitor, PD98059 to investigate the relationship between ERK1/2 MAPK and PA-induced Bcl-2 expression. PA-induced Bcl-2 expression was decreased when ERK1/2 was inhibited by PD98059. The transcription factor such as STAT3 which is controlled by ERK1/2 MAPK was increased along with $\mathrm{Bcl}-2$ expression
\end{abstract}

when the cells were treated with PA. Furthermore, STAT3 siRNA treatments inhibited PA-induced Bcl-2 expression, suggesting that STAT3 $\left(\mathrm{Ser}^{727}\right)$ is involved in PA-induced Bcl-2 expression. Taken together, these findings indicate that PA acts as an important mediator for increasing Bcl-2 expression through STAT3 $\left(\mathrm{Ser}^{227}\right)$ activation via the ERK1/2 MAPK pathway.

Keywords: extracellular signal-regulated MAP kinases; phosphatidic acids; phospholipases A2; proto-oncogene proteins c-bcl-2; STAT3 transcription factor

\section{Introduction}

Phosphatidic acid (PA), a lipid second messenger, is the simplest membrane phospholipid that has been implicated in various cellular processes; including signal transduction, membrane trafficking, secretion, and cytoskeletal rearrangement. PA acts as an effective mediator which has been linked to the survival and proliferation of cells and reproduction of organisms. Indeed, exogenous PA has the same mitogenic and biological effects; including growth stimulation of fibroblasts, induction of mRNA for proto-oncogenes, growth factors, activation of the neutrophil NADPH oxidase, and binding to neutrophils (Moolenaar et al., 1986; Siegmann, 1987; Knauss et al., 1990; Perry et al., 1993). However, the intracellular signaling mechanisms triggered by exogenously added PA are not clear.

PA has been reported to interact with a diversity of signaling molecules such as protein tyrosine kinase, ERK1/2 MAPK and phosphatidylinositol 3 kinase (Ghosh et al., 1996). ERK1/2 has been involved in the regulation of a variety of cellular processes (Lee et al., 2006). Recently, studies have reported that the ERK1/2 signaling pathway regulates the expression of $\mathrm{Bcl}-2$ and $\mathrm{Bcl}-\mathrm{X}_{\mathrm{L}}$, and promotes the survival of human pancreatic tumor cells (Boucher et al., 2000). Several MAPK family members including ERK, P38 MAPK, and JNK have been identified as kinases capable of phosphorylating $\mathrm{Ser}^{727}$ of STAT3 (Gotoh et al., 1996; Chung et al., 1997; $\mathrm{Ng}$ and Cantrell, 1997; Lim and Cao, 1999; Turkson et al., 1999; Yokogami et al., 2000).

Signal transducer and activator of transcription 3 (STAT3) is a key signal molecule for many cyto- 
kines and growth factor receptors (Heim et al., 1999) and is activated by phosphorylation at Tyr ${ }^{705}$, which induces dimerization, nuclear translocation and DNA binding (Darnell et al., 1994; Ihle, 1995). Also, STAT3 activation is also regulated by phosphorylation at $\operatorname{Ser}^{727}$ via the MAPK or mTOR pathway (Wen et al., 1995; Yokogami et al., 2000). In some studies, the STAT3 signal is mediated in survival for various tumor cell lines. Furthermore, STAT3 activation results in the upregulation of various genes involved in cell survival and proliferation; such as $\mathrm{Bcl}-2, \mathrm{Bcl}-\mathrm{X}_{\mathrm{L}} \mathrm{Mcl}-1$, cyclin $\mathrm{D}$, and c-Myc (Zushi et al., 1998; Bromberg et al., 1999; Rahaman et al., 2002).

In the present study, we investigated the mechanism of Bcl-2 upregulation by PA treatment. We found the effects of PA on Bcl-2 expression and obtained evidence that PA could up-regulate Bcl-2 expression by activation of ERK and phosphorylation of $\mathrm{Ser}^{727}$ in STAT3 in HeLa cells. These results suggest that $\mathrm{PA}$ is also a critical mediator in $\mathrm{Bcl}-2$ up-regulation.

\section{Results}

\section{PA increases the expression of $\mathrm{Bcl}-2$ protein}

To examine the effect of PA on protein expression of $\mathrm{Bcl}-2$, we treated HeLa cells with various concentrations of PA for $3 \mathrm{~h}$ and also treated the cells with $50 \mu \mathrm{M}$ PA for the indicated time. The expre- ssion of Bcl-2 protein reached a maximal level at $50 \mu \mathrm{M}$ PA for $3 \mathrm{~h}$ as shown in Figure $1 \mathrm{~A}$ and $\mathrm{B}$. Based on these results, we used $50 \mu \mathrm{M}$ PA for $3 \mathrm{~h}$ for optimal conditions of PA treatment with HeLa cells in the whole experiment.

\section{The PA-induced Bcl-2 expression was potentiated by propranolol, a PAP inhibitor, but inhibited by mepacrine, a PLA 2 inhibitor}

Next, we explored the mechanism of how PA upregulates an anti-apoptotic protein, Bcl-2. PA is converted into lyso-PA (LPA) by PLA 2 or DAG by PA-phosphohydrolase (Yon et al., 2003). Therefore, we checked the effect of propranolol, a well known PAP inhibitor, and mepacrine, a PLA 2 inhibitor, on mRNA and protein expression of Bcl-2. As shown in Figure 2A, PA-induced $\mathrm{Bcl}-2$ expression was more greatly increased by pretreatment with propranolol. On the other hand, as shown in Figure 2B, pretreatment with mepacrine blocked PAinduced $\mathrm{Bcl}-2 \mathrm{mRNA}$ and protein expression. This result suggests that PA- induced Bcl-2 mRNA and protein expression does not pass through the DAG pathway by PAP and that $\mathrm{PLA}_{2}$ is involved in $\mathrm{PA}$-induced $\mathrm{Bcl}-2$ protein and mRNA expression.

\section{DPPA leads to anti-apoptotic $\mathrm{Bcl}-2$ up-regulation}

$\mathrm{PLA}_{2}$ converts PA into AA or LPA (Erickson et al., 1999). To confirm which of the metabolites of PA
A

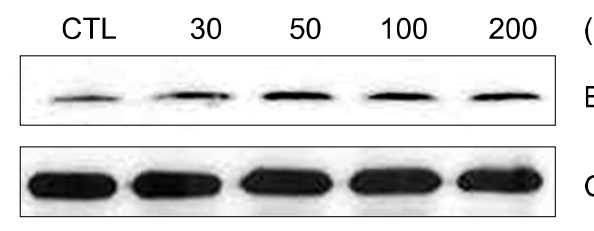

$(\mu \mathrm{M})$

$\mathrm{Bcl}-2$

GAPDH
B
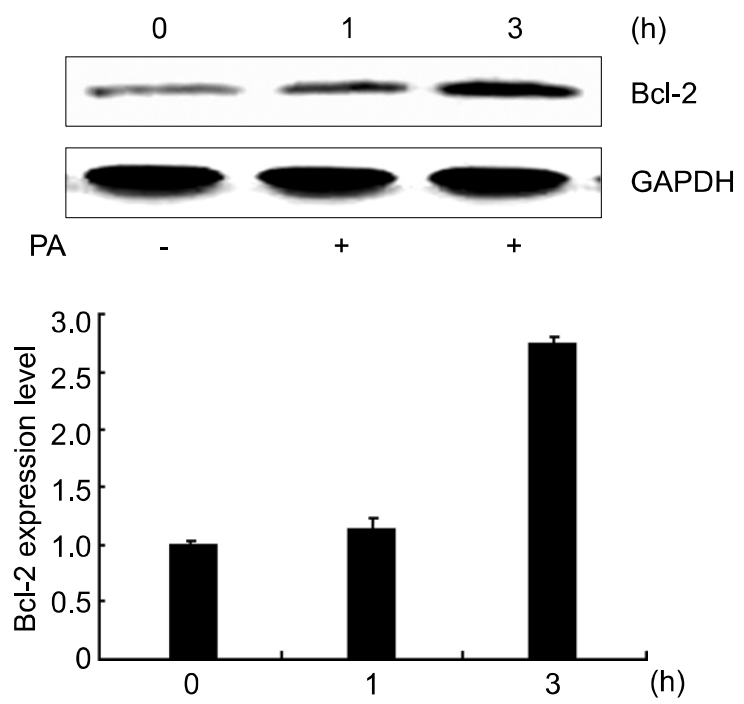

Figure 1. Effects of PA on the Bcl-2 expression in HeLa cells. PA increased Bcl-2 expression in both a dose- and time-dependent manner. (A) HeLa cells were cultured in DMEM containing 10\% FBS; HeLa cells were further incubated without FBS for $18 \mathrm{~h}$ and treated with different concentrations of PA for 3 h. (B) Cells treated with $50 \mu \mathrm{M}$ PA for the indicated time. The relative quantities of each protein band, normalized to control cells, were quantified using Quantity One software (Bio-Rad). 
A

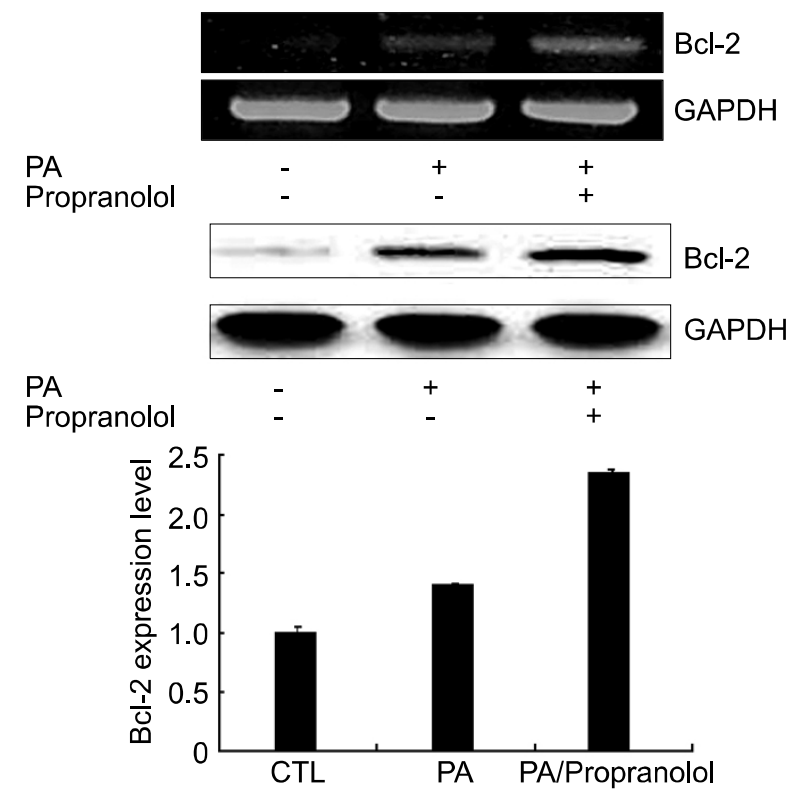

C

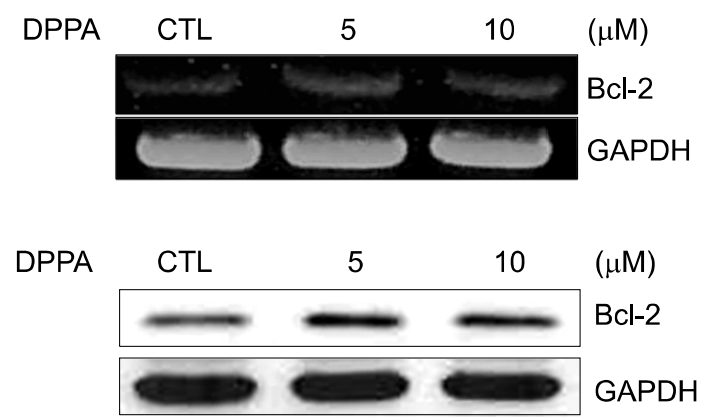

B

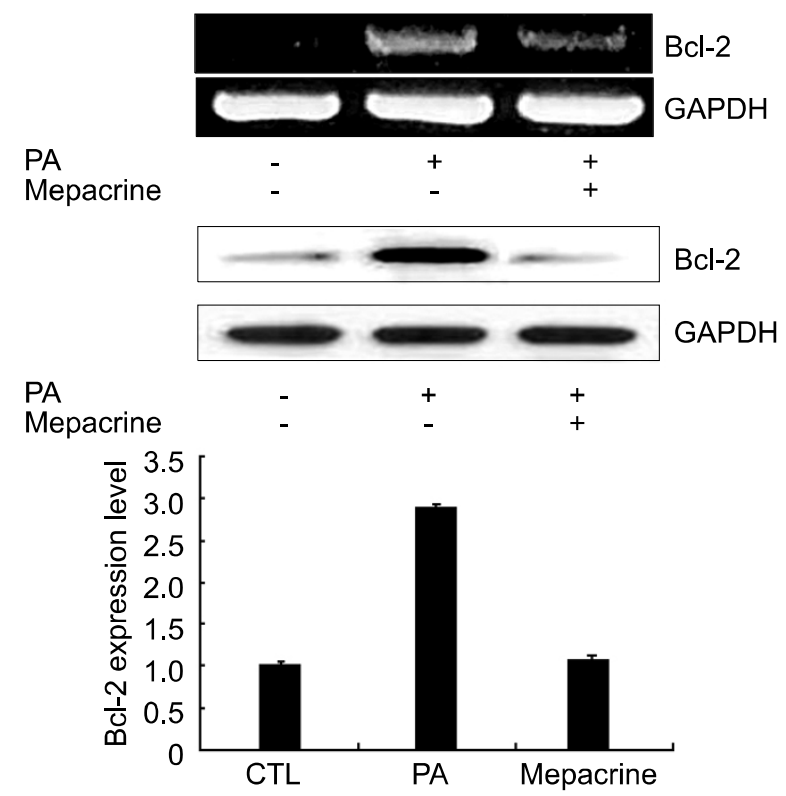

Figure 2. Effects of propranolol, mepacrine, and DPPA pretreatment on the expression of Bcl-2 in HeLa cells. (A) HeLa cells were pretreated with $50 \mu \mathrm{M}$ propranolol for $30 \mathrm{~min}$ before being treated with $50 \mu \mathrm{M}$ PA for $30 \mathrm{~min}$ for RT-PCR, and for $3 \mathrm{~h}$ for Western blotting. (B) HeLa cells were pretreated with 50 $\mu \mathrm{M}$ mepacrine for 30 min before $50 \mu \mathrm{M}$ PA treatmemt for $30 \mathrm{~min}$ for RT-PCR, and for $3 \mathrm{~h}$ for Western blotting, respectively. (C) HeLa cells were cultured for $1 \mathrm{~h}$ with 5 and $10 \mu \mathrm{M}$ DPPA after starvation for $18 \mathrm{~h}$, respectively. The upper panel represents mRNA expression and lower panel represents protein. The cells were harvested, lysised and subjected to RT-PCR and Western blotting as described in the Methods. The relative quantities of each protein band, normalized to control cells, were quantified using Quantity One software (Bio-Rad).

contribute to the increased $\mathrm{Bcl}-2$ mRNA and protein expression, we treated 1,2-dipalmitoyl-snglycero-3-phosphate (DPPA), PA that has no AA, for the indicated concentrations. We found that DPPA was able to increase the Bcl-2 mRNA and protein expression, as shown in Figure 2C. As a result, LPA, not AA acted as an important metabolite for the $\mathrm{Bcl}-2$ expression.

\section{ERK1/2 MAPK and STAT3 are involved in PA-induced Bcl-2 expression}

Exogenous PA has related mitogenic and biological effects. Some studies have reported that PA inter- acts directly with the serine-threonine kinase Raf-1, an important component of the MAPK signaling cascade (Ghosh et al., 1996). Recent studies report that $\mathrm{Bcl}-2$ expression is under the regulation of the STAT3 in B-non-Hodgkin's lymphoma (Alas and Bonavida, 2001). We determined whether treatment with PA relates to ERK1/2 MAPK and STAT3 $\left(\mathrm{Ser}^{27}\right.$ ) phosphorylation and Bcl-2 expression in HeLa cells. To confirm whether the $\mathrm{PLA}_{2}$ pathway is crucial in ERK1/2 MAPK and STAT3 $\left(\mathrm{Ser}^{727}\right)$ phosphorylation or $\mathrm{Bcl}-2$ expression, cells were treated with mepacrine, a $\mathrm{PLA}_{2}$ inhibitor. As a result, upon treatment with mepacrine, phosphorylation of ERK1/2 and STAT3 $\left(\mathrm{Ser}^{727}\right)$, as well as 
Bcl-2 expression after PA-stimulation, were partially reduced as shown in Figure $3 \mathrm{~A}$. Next we investigated whether ERK1/2 regulates PA-induced $\mathrm{Bcl}-2$ expression and phosphotylation of STAT3 $\left(\mathrm{Ser}^{727}\right)$ using PD98059, an ERK1/2 inhibitor in HeLa cells. ERK1/2 inhibitor, PD98059, inhibits the phosphorylation of STAT3 $\left(\mathrm{Ser}^{727}\right)$ and PA-induced $\mathrm{Bcl}-2$ expression, as shown in Figure 3B. These results suggest that ERK1/2 and STAT3 are located downstream of PLA $A_{2}$.

A
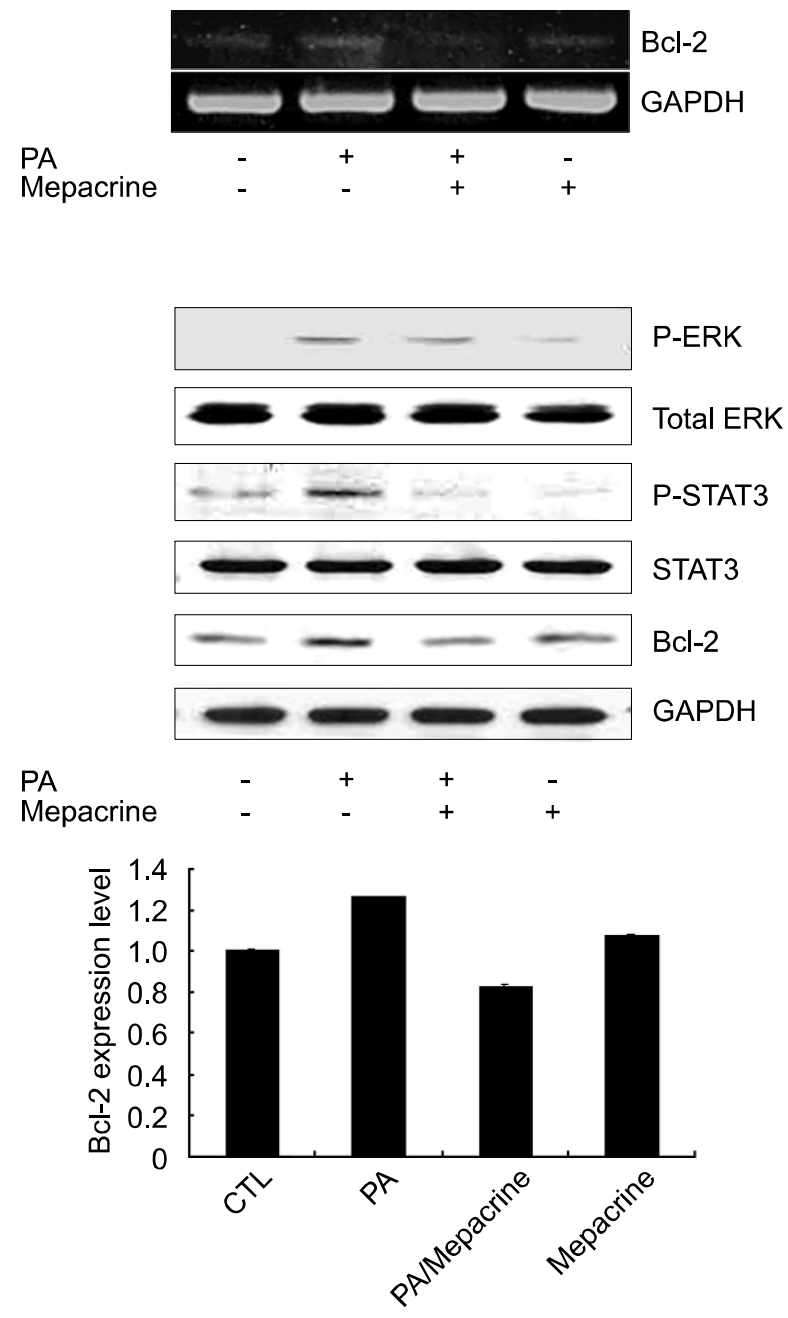

Treatment of STAT3 siRNA reduces STAT3 expression and PA-induced Bcl-2 expression

To determine whether STAT3 $\left(\mathrm{Ser}^{727}\right)$ could mediate the effect of PA-induced $\mathrm{Bcl}-2$ expression we treated HeLa cells with STAT3 siRNA to knockdown STAT3 expression. Scrambled siRNA was transfected as a control. As shown in Figure 4, STAT3 siRNA decreased PA-induced Bcl-2 expression as well as expression and $\operatorname{Ser}^{727}$ phosphorylation of STAT3 to control levels. This result su-

B
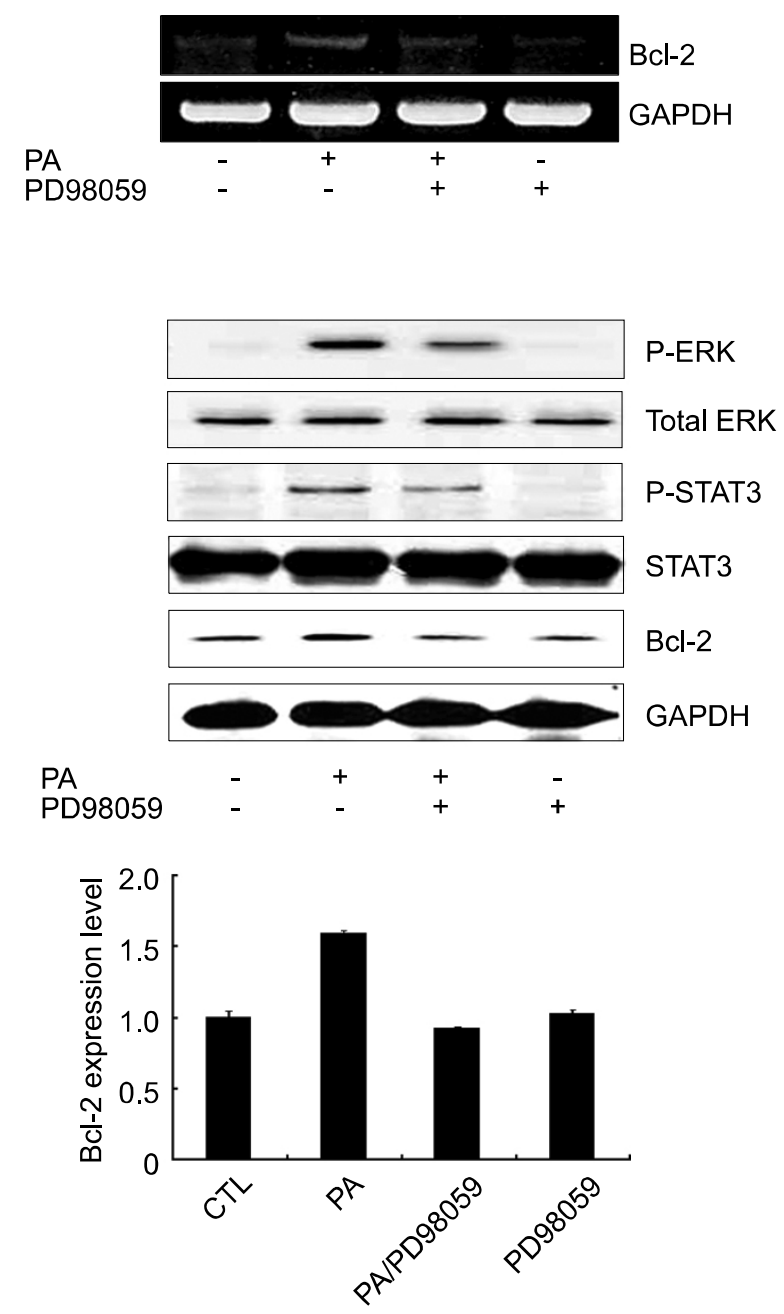

Figure 3. Effects of a PLA 2 inhibitor, mepacrine, and MEK inhibitor, PD98059, on PA-induced ERK1/2, STAT3 (Ser ${ }^{727}$ ) phosphorylation, and Bcl-2 expression in HeLa cells. (A) RNA was extracted from cells pretreated with $50 \mu \mathrm{M}$ mepacrine for $30 \mathrm{~min}$, followed by stimulation with $50 \mu \mathrm{M}$ PA for 30 min and Bcl-2 mRNA was amplified by RT-PCR. HeLa cells were pretreated with $50 \mu \mathrm{M}$ mepacrine for $30 \mathrm{~min}$, followed by stimulation with $50 \mu \mathrm{M}$ PA for 15 $\mathrm{min}$. Cell lysates were analyzed by immunoblotting with anti-ERK1/2, anti-STAT3, and phospho-ERK1/2, phospho-STAT3 (Ser ${ }^{727}$ ) antibodies. In the case of Bcl-2 Western blotting, cells were pretreated with $50 \mu \mathrm{M}$ mepacrine for $30 \mathrm{~min}$, followed by stimulation with $50 \mu \mathrm{M}$ PA for $3 \mathrm{~h}$. Cell lysates were analyzed by immunoblotting with Bcl-2 antibody. (B) RNA was extracted from cells treated with $50 \mu \mathrm{M}$ PD98059 for $1 \mathrm{~h}$, followed by stimulation with $50 \mu \mathrm{M}$ PA for 30 min and Bcl-2 mRNA was amplified by RT-PCR. HeLa cells were pretreated with $50 \mu \mathrm{M}$ PD98059 for $1 \mathrm{~h}$, followed by stimulation with $50 \mu \mathrm{M}$ PA for $15 \mathrm{~min}$. Cell lysates were analyzed by immunoblotting with anti-ERK1/2, STAT3, and phospho-ERK1/2, STAT3 (Ser ${ }^{72}$ ) antibodies. In the case of Bcl-2 Western blotting, cells were pretreated with $50 \mu \mathrm{M}$ PD98059 for $1 \mathrm{~h}$, followed by stimulation with $50 \mu \mathrm{M}$ PA for $3 \mathrm{~h}$. Cell lysates were analyzed by immunoblotting with Bcl-2 antibody. The relative quantities of each protein band, normalized to control cells, were quantified using Quantity One software (Bio-Rad). 

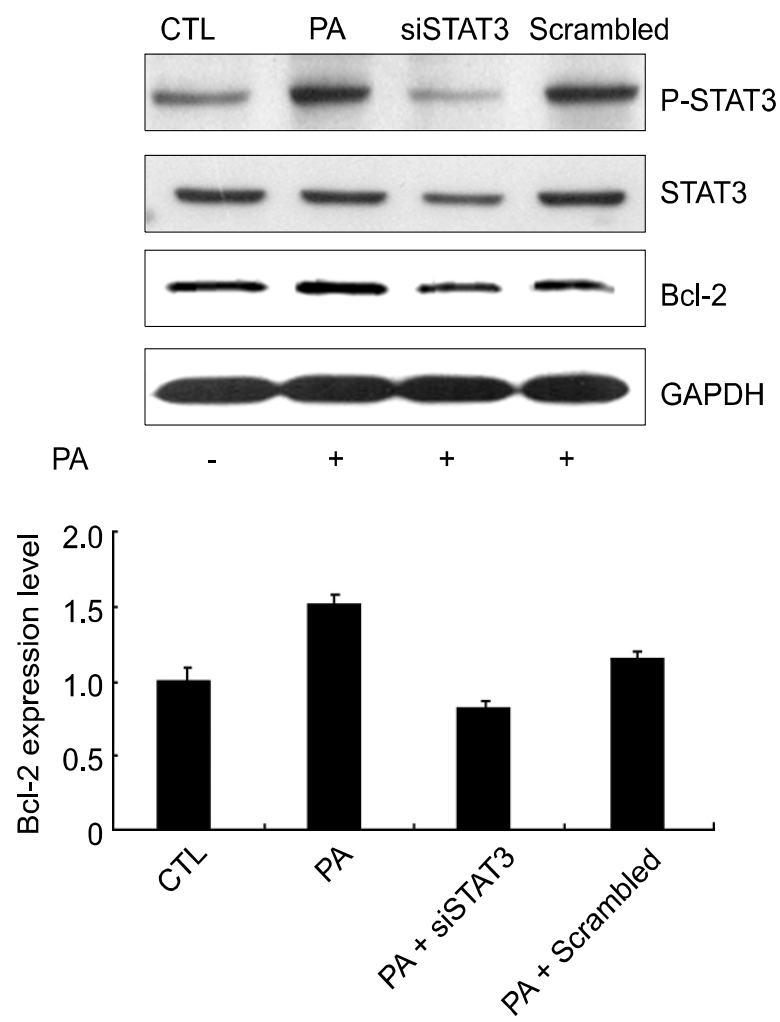

Figure 4. Effects of STAT3 siRNA on the expression of Bcl-2 in HeLa cells. HeLa cells were transiently transfected with $100 \mathrm{nM}$ STAT3 siRNA or scramble siRNA for $72 \mathrm{~h}$ and then stimulated with $50 \mu \mathrm{M}$ PA for 15 min (for p-STAT3/STAT3 blots) or $3 \mathrm{~h}$ (for Bcl-2 blots). Expression level of p-STAT3 $\left(\mathrm{Ser}^{727}\right)$, STAT3, and Bcl-2 were determined by Western blot analysis. The relative quantities of each protein band, normalized to control cells, were quantified using Quantity One software (Bio-Rad).

pports that STAT3 $\left(\mathrm{Ser}^{727}\right)$ is directly related to $\mathrm{PA}$-induced $\mathrm{Bcl}-2$ expression.

\section{Discussion}

$\mathrm{Bcl}-2$, a proto-oncogene, was first identified as an oncoprotein coded by a gene translocation of chromosomes 14:18 and induced in follicular B-cell lymphomas (Tsujimoto et al., 1985). Bcl-2 prevents IL-3-dependent cells from apoptotic death upon withdrawal of the cytokine (Vaux et al., 1988). Members of the Bcl-2 family are classified as antiapoptotic factors, which include $\mathrm{Bcl}-2, \mathrm{Bcl}-\mathrm{xL}$, $\mathrm{Mcl}-1$, and others. The proapoptotic members can be separated into two subgroups: the Bax subfamily (Bax, Bak and Bok), which contain multiple $\mathrm{BH}$ domains, and the $\mathrm{BH} 3$-only family including Bad, Bid, Bim, Noxa, Hrk, and others (Huang and Strasser, 2000; Adams and Cory, 2001; Newmeyer and Ferguson-Miller, 2003; Tsujimoto, 2003; Choi et al., 2006). Bcl-2 protein is the most important regulator

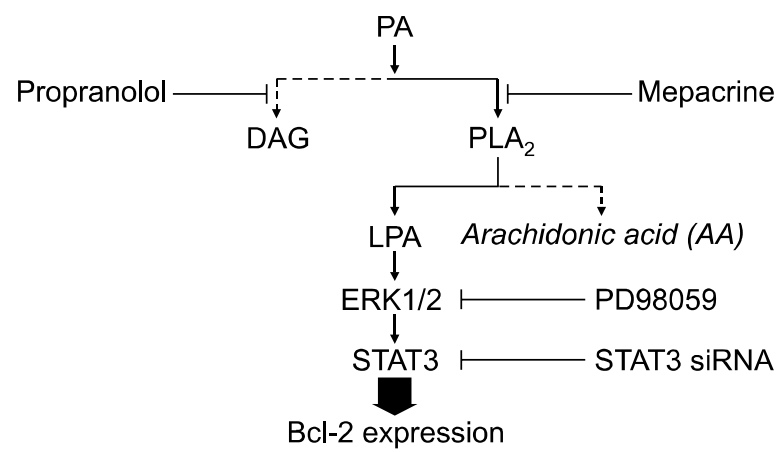

Figure 5. A proposed model for the signaling pathway of PA-induced $\mathrm{BCl}-2$ expression. We diagramed a mechanism of up-regulation of $\mathrm{BCl}-2$ expression induced by PA. PA can be converted to LPA by $\mathrm{PLA}_{2}$, but does not pass through the DAG pathway by PAP. Subsequently, LPA acts as an important signal molecule to upregulate Bcl-2 expression. PA leads to activation of downstream kinases, ERK1/2, which are responsible for the phosphorylation of STAT3 $\left(\mathrm{Ser}^{\text {T27 }}\right)$.

of apoptosis and is involved in the regulation of the cell cycle (O'Reilly et al., 1997), prolongs cell survival (Korsmeyer, 1992), and inhibits apoptosis (O'Reilly et al., 1997). Several studies have reported that $\mathrm{Bcl}-2$ modulates cell differentiation (Lu et al., 1995) and gene expression (Miyashita et al., 1995) and also regulates the transactivity of several transcription factors such as NF-kB (Ricca et al., 2000), and p53 (Froesch et al., 199). Furthermore $\mathrm{Bcl}-2$ regulates outer mitochondrial membrane permeability and release of cytochrome $C$ and other apoptogenic factors (Huang and Strasser, 2000; Adams and Cory, 2001; Newmeyer and Ferguson-Miller, 2003; Tsujimoto, 2003; Choi et al., 2006). Previously, we reported that PA produced by PLD raises Bcl-2 protein expression in several cells lines (Oh et al., 2007; Cho et al., 2008). However, how PA regulates $\mathrm{Bcl}-2$ expression has not been studied yet.

When we treated HeLa cells with PA, Bcl-2 expression was increased in both a dose- and timedependent manner. However PA did not show any effect on the expression of another antiapoptotic protein, such as $\mathrm{Bcl}-\mathrm{xL}$ (data not shown). PA can be degraded into arachidonic acid (AA) and lysoPA (LPA) by $P L A_{2}$. AA, a polyunsaturated fatty acid, can be converted to prostaglandin by cyclooxygenase (COX) (Herrmann et al., 1997). To find out whether $\mathrm{PLA}_{2}$, a product of $\mathrm{PA}$, was involved in the increased expression of $\mathrm{Bcl}-2$ in HeLa cells, we used DPPA, which has two palmitic acids instead of AA. DPPA treatment also increased $\mathrm{Bcl}-2$ expression, indicating that LPA, not $A A$, is an important mediator in down stream of PA for the induction of Bcl-2 expression.

Recently, the MAPK cascade, which is well known for cell proliferation and differentiation including cell 
signaling, were studied to be associated with the apoptotic pathway (Kim et al., 2003). Ghosh et al. (1996) first proposed that PA is a regulator of the ERK phosphorylation cascade. ERK, P38 MAPK, and JNK have been identified as kinases capable of phosphorylationg serine 727 of STAT3 (Gotoh et al., 1996; Chung et al., 1997; Ng and Cantrell, 1997; Lim and Cao, 1999; Turkson et al., 1999; Yokogami et al., 2000). Indeed, the transcriptional activity of STAT3 via Ser ${ }^{727}$ phosphorylation was modulated by ERK (Chung et al., 1997). Interestingly, STAT3 is an important transcription factor for the regulation of $\mathrm{Bcl}-2$ gene expression in B-nonHodgkin's lymphoma (Alas and Bonavida, 2001). To establish the relationship between PA and ERK1/2/STAT3 $\left(\mathrm{Ser}^{727}\right.$ ), we examined whether the ERK1/2 and STAT3 $\left(\mathrm{Ser}^{727}\right)$ were activated by PA. We found that activation of ERK1/2 and STAT3 $\left(\mathrm{Ser}^{727}\right)$ through PA treatment are completely abolished by pretreatment with mepacrine, a $\mathrm{PLA} 2$ inhibitor. The inhibition of MEK1/2 by PD98059 also led to the suppression of PA-induced $\mathrm{Bcl}-2$ expression and phosphorylation of STAT3 $\left(\mathrm{Ser}^{727}\right)$. We further investigated the involvement of STAT3 $\left(\mathrm{Ser}^{727}\right)$ in $\mathrm{Bcl}-2$ up-regulation by using STAT3 siRNA. As expected, knockdown of STAT3 showed a decrease in PA-induced $\mathrm{Bcl}-2$ expression. These results strongly suggest that activation of ERK1/2 and STAT3 $\left(\operatorname{Ser}^{727}\right)$ were closely related to the $\mathrm{PA}$-induced $\mathrm{Bcl}-2$ expression pathway.

Taken together, results in the present study indicate that PA acts as an important regulator during $\mathrm{Bcl}-2$ up-regulation in HeLa cells. On top of this result, LPA is also responsible for increasing PAinduced $\mathrm{Bcl}-2$ expression in HeLa cells through activating ERK1/2 and STAT3.

\section{Methods}

\section{Materials}

FBS, penicillin/streptomycin solution, and DMEM with L-glutamine and low glucose were purchased from GibcoBRL (MD). Bcl-2 monoclonal antibody and GAPDH polyclonal antibody were obtained from Santa Cruz Biotechnology (CA). ERK1/2 polyclonal antibody and p-ERK1/2 monoclonal antibody, STAT3 polyclonal antibody and pSTAT3 $\left(\mathrm{Ser}^{727}\right)$ polyclonal antibody were obtained from Cell signaling (MA). Propranolol and mepacrine were purchased from Sigma-Aldrich (MO). 1,2-dipalmitoyl-sn- glycero-3phosphate (DPPA) was purchased from Avanti Polar Lipids (Alabaster, AL). 1,2-dioctanoly-sn-glycerol-3-phosphate sodium salt (PA) was purchased from Sigma- Aldrich (MO). PD98059 was purchased from Calbiochem (CA).

\section{Cell culture}

HeLa cells were incubated for 2 days at $37^{\circ} \mathrm{C}$ in DMEM supplemented with $10 \%(\mathrm{v} / \mathrm{v})$ heated-inactivated FBS, 100 units $/ \mathrm{ml}$ penicillin, and $100 \mu \mathrm{g} / \mathrm{ml}$ streptomycin. Cells were grown at $37^{\circ} \mathrm{C}$ in a humidified $\mathrm{CO}_{2}$-controlled (5\%) incubator, then washed with DMEM medium containing $0.1 \%(\mathrm{w} / \mathrm{v}) \mathrm{BSA}, 100 \mathrm{units} / \mathrm{ml}$ penicillin, and $100 \mu \mathrm{g} / \mathrm{ml}$ streptomycin (serum-free medium) and incubated in a serum-free medium at $37^{\circ} \mathrm{C}$ for $18 \mathrm{~h}$ before treatment.

\section{Reverse transcriptase polymerase chain reaction (RT-PCR)}

cDNA was made from total mRNA extracted from cells. Total cellular RNA was isolated using Trizol reagent (Life Technologies Inc., Rockville, MD) according to the manufacturer's instructions. For the reverse transcriptase reaction, $5 \mu \mathrm{g}$ of total RNA was mixed with oligo $(\mathrm{dT})_{16}$ primer and Maloney murine leukemia virus (M-MLV) reverse transcriptase (Promega, Madison, WI), and the mixture was incubated for $60 \mathrm{~min}$ at $42^{\circ} \mathrm{C}$. The transcribed products were mixed with each primer set and Taq DNA polymerase (Takara Shuzo, Japan), and then amplified. Bcl-2 sense 5'-CATTTCCACGTCAACAGAATTG-3' and antisense 5'-AGCACAGGATTGGATATTCCAT-3 (PCR product, 505bp)': GAPDH sense: 5'-GCTCAGACACCATGGGGAAGGT-3' and antisense: 5'-GTGGTGCAGGAGGCATTGCTGA (PCR product, $473 \mathrm{bp}$ ). The PCR products were analyzed in $1.2 \%$ agarose-gel.

\section{Western blot analysis}

Cells were washed twice with ice-cold PBS and scraped in PBS, then harvested by microcentrifugation. The cells were then resuspended in $0.5 \mathrm{ml}$ of lysis buffer $(50 \mathrm{mM}$ Tris- $\mathrm{HCl}, \mathrm{pH}$ 7.5, $150 \mathrm{mM} \mathrm{NaCl}, 1 \mathrm{mM}$ EDTA, 1 mM EGTA, $1 \mathrm{mM} N A F, 1 \mathrm{mM} \mathrm{Na} \mathrm{VO}_{4}, 1 \mathrm{mM}$ PMSF, $1 \%$ Triton X-100, $0.5 \% \mathrm{NP}-40,10 \mu \mathrm{g} / \mathrm{ml}$ aprotinin, $10 \mu \mathrm{g} / \mathrm{ml}$ leupeptin) on ice and disrupted by sonication. Cell lysates were centrifuged for $10 \mathrm{~min}$ at $10,000 \times \mathrm{g}$ at $4^{\circ} \mathrm{C}$. Proteins $(30 \mu \mathrm{g}$ of protein/ lane) from control or treated cells were resolved by SDSPAGE and transferred to nitrocellulose membranes using a Bio-Rad semi-dry transfer system. The membranes were blocked for $1 \mathrm{~h}$ with $5 \%(\mathrm{v} / \mathrm{v})$ non-fat milk in TTBS (trisbuffered saline containing $0.1 \%$ Tween 20 ) and then incubated with diluted specific antibody $(1 \mu \mathrm{g} / \mathrm{ml})$ for another hour. Unbound primary antibodies were removed by three washes (5 min each) with TTBS. The membranes were then incubated with HRP-coupled goat anti-rabbit or antimouse IgG (diluted 1:1000 with TTBS; KPL, Gaithersburg, MD) for $1 \mathrm{~h}$, followed by three washes (5 min each) in TTBS. Visualization of signals was achieved by using chemiluminescence (ECL reagent, Amersham Biosciences) according to the manufacturer's protocol. Protein concentrations were routinely determined by the Bradford procedure with Bio-Rad dye reagent and BSA as a standard.

\section{Small interference RNA (siRNA) synthesis and transfection}

Human STAT3 siRNA was purchased from Ambion (Austin, TX). A human STAT3 sequence (sense: 5'-AACUUC- 
AGACCCGUCAACAAAdTdT-3'; antisense 5'-UUUGUUGACGGGUCUGAAGUUdTdT-3') was chosen for STAT3 RNAi targeting. The siRNA was transiently transfected into the HeLa cell $\left(3 \times 10^{5}\right.$ cells/well; 6 -well plate) using the NeoFX reagent and $72 \mathrm{~h}$ after tranfection, the cells were harvested for Western blotting. A negative control was carried out with Negative Control siRNA\#2 (from Ambion).

\section{Statistical analysis}

All experiments were performed at least three times in triplicate, and results were expressed as mean value of \pm $\mathrm{SD}$. The significance of differences were assessed by an unpaired $t$-test.

\section{Acknowledgements}

This work was supported by the research fund of Hanyang University (HY-2004-N), and the Korea Science and Engineering Foundation (KOSEF) grant funded by the Korea government (MEST) (R13-2008-026-01000-0).

\section{References}

Adams JM, Cory S. Life-or-death decisions by the Bcl-2 protein family. Trends Biochem Sci 2001;26:61-6

Alas S, Bonavida B. Rituximab inactivates signal transducer and activation of transcription 3 (STAT3) activity in B-nonHodgkin's lymphoma through inhibition of the interleukin 10 autocrine/paracrine loop and results in down-regulation of $\mathrm{Bcl}-2$ and sensitization to cytotoxic drugs. Cancer Res 2001;61:5137-44

Boucher MJ, Morisset J, Vachon PH, Reed JC, Laine J, Rivard N. MEK/ERK signaling pathway regulates the expression of $\mathrm{Bcl}-2, \mathrm{Bcl}-\mathrm{X}(\mathrm{L})$, and $\mathrm{Mcl}-1$ and promotes survival of human pancreatic cancer cells. J Cell Biochem 2000;79:355-69

Bromberg JF, Wrzeszczynska MH, Devgan G, Zhao Y, Pestell RG, Albanese C, Darnell JE Jr. Stat3 as an oncogene. Cell 1999;98:295-303

Cho JH, Hong SK, Kim EY, Park SY, Park CH, Kim JM, Kwon OJ, Kwon SJ, Lee KS, Han JS. Overexpression of phospholipase D suppresses taxotere-induced cell death in stomach cancer cells. Biochim Biophys Acta 2008;1783: 912-23

Choi YK, Kim TK, Kim CJ, Lee JS, Oh SY, Joo HS, Foster DN, Hong KC, You S, Kim H. Activation of the intrinsic mitochondrial apoptotic pathway in swine influenza virusmediated cell death. Exp Mol Med 2006;38:11-7

Chung J, Uchida E, Grammer TC, Blenis J. STAT3 serine phosphorylation by ERK-dependent and -independent pathways negatively modulates its tyrosine phosphorylation. Mol Cell Biol 1997;17:6508-16

Darnell JE Jr, Kerr IM, Stark GR. Jak-STAT pathways and transcriptional activation in response to IFNs and other extracellular signaling proteins. Science 1994;264:1415-21 Erickson RW, Langel-Peveri P, Traynor-Kaplan AE, Hey- worth PG, Curnutte JT. Activation of human neutrophil NADPH oxidase by phosphatidic acid or diacylglycerol in a cell-free system. Activity of diacylglycerol is dependent on its conversion to phosphatidic acid. J Biol Chem 1999;274: 22243-50

Froesch BA, Aime-Sempe C, Leber B, Andrews D, Reed JC. Inhibition of p53 transcriptional activity by $\mathrm{Bcl}-2$ requires its membrane-anchoring domain. J Biol Chem 1999;274: 6469-75

Ghosh S, Strum JC, Sciorra VA, Daniel L, Bell RM. Raf-1 kinase possesses distinct binding domains for phosphatidylserine and phosphatidic acid. Phosphatidic acid regulates the translocation of Raf-1 in 12-O-tetradecanoylphorbol-13-acetate-stimulated Madin-Darby canine kidney cells. J Biol Chem 1996;271:8472-80

Gotoh A, Takahira H, Mantel C, Litz-Jackson S, Boswell HS, Broxmeyer HE. Steel factor induces serine phosphorylation of Stat3 in human growth factor-dependent myeloid cell lines. Blood 1996;88:138-45

Heim MH. The Jak-STAT pathway: cytokine signalling from the receptor to the nucleus. J Recept Signal Transduct Res 1999;19:75-120

Herrmann JL, Menter DG, Beham A, von Eschenbach A, McDonnell TJ. Regulation of lipid signaling pathways for cell survival and apoptosis by bcl-2 in prostate carcinoma cells. Exp Cell Res 1997;234:442-51

Huang DC, Strasser A. BH3-Only proteins-essential initiators of apoptotic cell death. Cell 2000;103:839-42

Ihle JN. Cytokine receptor signaling. Nature 1995;377:591-4

Kim HJ, Yang SJ, Kim YS, Kim TU. Cobalt chloride-induced apoptosis and extracellular signal-regulated protein kinase activation in human cervical cancer HeLa cells. J Biochem Mol Biol 2003;36:468-74

Knauss TC, Jaffer FE, Abboud HE. Phosphatidic acid modulates DNA synthesis, phospholipase $C$, and plateletderived growth factor mRNAs in cultured mesangial cells. Role of protein kinase C. J Biol Chem 1990;265:14457-63

Korsmeyer SJ. Bcl-2 initiates a new category of oncogenes: regulators of cell death. Blood 1992;80:879-86

Lee DY, Lee MW, Lee HJ, Noh YH, Park SC, Lee MY, Kim KY, Lee WB, Kim SS. ERK1/2 activation attenuates TRAILinduced apoptosis through the regulation of mitochondriadependent pathway. Toxicol In Vitro 2006;20:816-23

Lim CP, Cao X. Serine phosphorylation and negative regulation of Stat3 by JNK. J Biol Chem 1999;274:31055-61

Lu PJ, Lu QL, Rughetti A, Taylor-Papadimitriou J. Bcl-2 overexpression inhibits cell death and promotes the morphogenesis, but not tumorigenesis of human mammary epithelial cells. J Cell Biol 1995;129:1363-78

Miyashita T, Kitada S, Krajewski S, Horne WA, Delia D, Reed JC. Overexpression of the $\mathrm{Bcl}-2$ protein increases the half-life of p21Bax. J Biol Chem 1995;270:26049-52

Moolenaar WH, Kruiger W, Tilly BC, Verlaan I, Bierman AJ, de Laat SW. Growth factor-like action of phosphatidic acid. Nature 1986;323:171-3 
Newmeyer DD, Ferguson-Miller S. Mitochondria: releasing power for life and unleashing the machineries of death. Cell 2003;112:481-90

$\mathrm{Ng} \mathrm{J}$, Cantrell D. STAT3 is a serine kinase target in T lymphocytes. Interleukin 2 and T cell antigen receptor signals converge upon serine 727. J Biol Chem 1997;272:24542-9

Oh KJ, Lee SC, Choi HJ, Oh DY, Kim SC, Min DS, Kim JM, Lee KS, Han JS. Role of phospholipase D2 in anti-apoptotic signaling through increased expressions of $\mathrm{Bcl}-2$ and $\mathrm{Bcl}-\mathrm{xL}$. J Cell Biochem 2007;101:1409-22

O'Reilly LA, Harris AW, Strasser A. Bcl-2 transgene expression promotes survival and reduces proliferation of CD3-CD4-CD8- T cell progenitors. Int Immunol 1997;9: 1291-301

Perry DK, Stevens VL, Widlanski TS, Lambeth JD. A novel ecto-phosphatidic acid phosphohydrolase activity mediates activation of neutrophil superoxide generation by exogenous phosphatidic acid. J Biol Chem 1993;268:25302-10

Rahaman SO, Harbor PC, Chernova O, Barnett GH, Vogelbaum MA, Haque SJ. Inhibition of constitutively active Stat3 suppresses proliferation and induces apoptosis in glioblastoma multiforme cells. Oncogene 2002;21:8404-13

Ricca A, Biroccio A, Del Bufalo D, Mackay AR, Santoni A, Cippitelli M. Bcl-2 over-expression enhances NF-kappaB activity and induces mmp-9 transcription in human MCF7 (ADR) breast-cancer cells. Int J Cancer 2000;86:188-96

Siegmann DW. Stimulation of quiescent $3 T 3$ cells by phosphatidic acid-containing liposomes. Biochom Biophys Res Commun 1987;145:228-33
Tsujimoto Y, Cossman J, Jaffe E, Croce CM. Involvement of the bcl-2 gene in human follicular lymphoma. Science 1985;228:1440-3

Tsujimoto Y. Cell death regulation by the Bcl-2 protein family in the mitochondria. J Cell Physiol 2003;195:158-67

Turkson J, Bowman T, Adnane J, Zhang Y, Djeu JY, Sekharam M, Frank DA, Holzman LB, Wu J, Sebti S, Jove R. Requirement for Ras/Rac1-mediated p38 and c-Jun $\mathrm{N}$-terminal kinase signaling in Stat3 transcriptional activity induced by the Src oncoprotein. Mol Cell Biol 1999;19:751928

Vaux DL, Cory S, Adams JM. Bcl-2 gene promotes haemopoietic cell survival and cooperates with c-myc to immortalize pre-B cells. Nature 1988;335:440-2

Wen Z, Zhong Z, Darnell JE Jr. Maximal activation of transcription by Stat 1 and Stat 3 requires both tyrosine and serine phosphorylation. Cell 1995;82:241-50

Yokogami K, Wakisaka S, Avruch J, Reeves SA. Serine phosphorylation and maximal activation of STAT3 during CNTF signaling is mediated by the rapamycin target mTOR. Curr Biol 2000;10:47-50

Yon C, Lee MH, Oh DY, Kim DS, Lee KS, Han JS. Advanced lipid extraction method for the determination of the phospholipase D activity. Arch Pharm Res 2003;26:478-81

Zushi S, Shinomura Y, Kiyohara T, Miyazaki Y, Kondo S, Sugimachi M, Higashimoto Y, Kanayama S, Matsuzawa Y. STAT3 mediates the survival signal in oncogenic rastransfected intestinal epithelial cells. Int J Cancer 1998;78: 326-30 